\title{
EFFECT OF VINASSES, MOLASSES AND MINERAL FERTILIZATION ON NODULATION AND GROWTH OF COMMON BEAN (PHASEOLUS VULGARIS L.) GROWN IN SANDY RECLAIMED SOILS
}

\author{
E. A. Abou-Husssien, H. M. El-Zemrany and M. B. Hammad \\ Dept. of Soil Sci., Fac. of Agric., Minoufia Univ., Egypt
}

Received: Nov. 27, 2019

Accepted: Dec. 5, 2019

\begin{abstract}
The present work was conducted to achieve the following aims: Evaluate the effect of both individual and combined applications of either of molasses or concentrated vinasse with mineral fertilizers i.e. phosphoric acid and mixture of micronutrients (Fe-Zn-Mn-Cu-B-Mo), which added in equal five dosses at different growth times to two cultivars of common bean plants (Phaseolus vulgaris L.) i.e, Karnak and Nebraska grown in sandy soil under drip irrigation systems on: nodulations efficiency, dehydrogenase activities at growth period of 45 days. As well as the dry matter yield of common bean plants and was determined, at growth periods of 45 and 70 days.
\end{abstract}

The obtained data of this study show that, the two local cultivars of common bean plants (Karnak and Nebraska) appeared a wide variations to the studied treatments. The fertilization treatments under study resulted in a significant increase of nodules number formed on the roots, dehydrogenase activity and dry matter yields, where the highest values were found with Nebraska cultivar compared with those of Karnak cultivar.

Key wards: Common beans cultivars, Sandy soil Vinaasse, Molasses, Nodulation, Phosphorus and Micronutrients

\section{INTRODUCTION}

Legume crops are not only used as human diet but also for improving soil fertility through its effective role in biological nitrogen fixation. Among to the grain legumes, common bean (Phaseolus vulgaris L.) is the most important pulse crop in the world. It is an important source of calories, proteins, dietary fibers, minerals and vitamins for millions of people in both developing and developed countries (Elkhatib, $r . . q$ ). Egypt is the main exporter of dry and green beans. Therefore the expansion in dry and green bean cultivation has exhibited impressive growth during the past several years with a cultivated area in 2016 of $\mathbf{1 0 5 3 7 7}$ ha with a production of 287575 tons and 33135 ha with a production of 112925 tons of green and dry beans, respectively (FAO, 2013). Any advances in scientific research that benefit bean yields, particularly in developing countries, help to feed the hungry and give hope for the future (FAO, 2016).

Cultivation of leguminous crops can be an alternative source of nutrients as it is a renewable and eco-friendly source of $\mathrm{N}$ (Oldroyd and Dixon, 2014). Among the nutrients, deficiency of phosphorus $(P)$ in soil has an adverse impact on legume production as it is required for energy transformation in nodules and enhanced N-fixation (Rotaru and Sinclair, 2009; Udvardi and Poole, 2013 and Yadav et al., 2017).

The legume crops have more demand for $\mathrm{P}$ for optimal $\mathrm{N}$-fixation compared to non-modulating plants like cereals because of $P$ having a crucial role in nodule energetic transformations (Rotaru and Sinclair, 2009). Therefore, P-deficient 
soil and low availability impose major restrictions on the vegetative and reproductive growth development of crop (Vance et al., 2003 and Zhang et al., 2014). Thus, application of an optimum dose of $P$ fertilizer has a significant influence on improving growth and productivity of legume crops. Micronutrient deficiency in soil is a global phenomenon, although to varying extents for the different micronutrients (Voortman and Bindraban, 2015).

There is no doubt that without micronutrients, many of the processes that drive plant metabolism of $\mathrm{N}, \mathrm{P}, \mathrm{K}$, $\mathrm{Mg}, \mathrm{Ca}$, and $\mathrm{S}$, as well as crop responses to ecological perturbations, would not be optimally functional. Iron, $\mathrm{Cu}$, and $\mathrm{Mn}$ are involved in different aspects of plant photosynthesis, as cofactors for different metabolic processes. Dependent on the enzyme, $\mathrm{Fe}, \mathrm{Mn}, \mathrm{Zn}, \mathrm{Cu}, \mathrm{Ni}, \mathrm{Mo}$, and $\mathrm{Cl}$ all participate in the functioning of different enzymes, including DNA/RNA polymerases, N-metabolizing enzymes, superoxide dismutases, catalases, dehydrogenases, oxidases, ATPases, and numerous other enzymes involved in redox processes (Broadley et al. 2012). This cofactor role of micronutrients is crucial for enzyme and nonenzyme activities in plant metabolism under different environmental conditions. For instance, $\mathrm{Zn}$ specifically plays a role in the enzymatic processes involved in the biosynthesis of the plant growth regulator, auxin (Fageria, 2002).

The use of molasses and vinasse in fertigation are increasing in several agricultural areas, substituting for potassium mineral fertilizers and furnishing water, organic matter, and other mineral nutrients in smaller quantities. The use of both molasses and vinasse should be optimized for each agricultural system and follow recommendations of responsible organisations to prevent environmental damage. The use of vinasse in fertigation systems has advantages because it can contribute substantial amounts of water and mineral nutrients, support soil quality and crop productivity, and finally, but no less importantly, can solve the environmental problem of the disposal of this agro-industrial residue (Prado et al., 2013).

In Egypt, the sugar and integrated industries company (Hawamdyia) produce more than $2,000 \mathrm{M}^{3} \mathrm{~d}^{-1}$ of vinasse. It represents residues from molasses fermentation processes. The large amount of vinasse can harm the environment, causing salinization and river Nile pollution. Therefore, it was though useful to try overcoming the created problem using it in agriculture land. It is largely composed of water, organic matter, and mineral elements. Results from such studies indicate that, properly used, vinasse contributes to improvements in soil quality and agricultural productivity (Jiang et al., 2012).

The objective of this study is to evaluate the effect of nutritional value of both molasses and concentrated vinasse (Egyptian Sugar and Integrated Industries Company SAE) as organic fertilizers and mineral fertilizers i.e. phosphorus with some microelements (Fe-Zn-Mn-Cu-B-Mo), which added at several growth times individually and in together on the nodulation, dehydrogenase activities in the rhizospheric soil and dry matter yields of two local common bean cultivars (Karnake and Nebraska) cultivated in sandy soil of Egypt.

\section{MATERIALS AND METHODS}

Before planting, surface soil samples $(0-20 \mathrm{~cm})$ were taken from the experimental soil of Elmarraka Village, Tahrire regions (Latitude $30^{\circ} .42 \mathrm{~N}$ Longitude $\left.\quad 30^{\circ} .31^{\prime} \mathrm{E}\right) \quad-\quad$ Beheira 
Governorate, Egypt. These soil samples air-dried, ground, well mixed and sieved through a $2 \mathrm{~mm}$ sieve. The fine and sieved $(>2 \mathrm{~mm}$ ) soil was analyzed for some physical and chemical physical properties and its content of total and available macro-and micronutrients as described by Cottenie et al. (1982), Klute (1986) and Page et al. (1982). The obtained data are recorded in Table (1).

\section{Organic fertilizers}

In this study two organic fertilizers were used molasses (Mol) and concentrated vinasse (Vin) which taken from Egyptian Sugar and Integrated Industries Company SAE, Egypt. The used (Mol) and (Vin) were analyzed for some physical and chemical characters as well as their content of essential of plant nutrients according to the methods described by Klute (1986) and Page et al.
(1982) and the obtained data are recorded in Tables (2 and 3), respectively.

\section{Mineral fertilizers}

The used mineral fertilizers in this study were:

a- Phosphoric acid $\left(\mathrm{H}_{3} \mathrm{PO}_{4}\right)$, which characterized by: specific density of $1.54 \mathrm{gm} \mathrm{cm}^{-3}$, purity percent of $85 \%$, and $41.4 \% \mathrm{P}\left(95.22 \% \mathrm{P}_{2} \mathrm{O}_{5}\right)$.

b- One $\mathrm{Kg} \mathrm{fed}^{-1}$ of micronutrients mixtures contain: $12 \% \mathrm{Fe}, 12 \% \mathrm{Mn}$, $13 \% \mathrm{Zn}$, and $13 \% \mathrm{Cu}$ were used in the form of EDTA (ethylenediamin tetra acetic Acid), $100 \mathrm{~g} \mathrm{fed}^{-1}$ of molybdinum (Mo) was used as ammonium molybidate form (Mo, $50 \%$ ), and $0.5 \mathrm{Kg} \mathrm{fed}^{-1}$ of boron (B) was used as boric acid form ( $B$, iv $\%)$.

Table (1): Physical and chemical properties and nutrient contents of the field experimental soil at Elmarraka, Tahrire regions, Beheira Governorate, Egypt.

\begin{tabular}{|c|c|c|}
\hline Properties and unit & & Values \\
\hline $\begin{array}{l}\text { Particle fraction: } \\
\qquad \begin{array}{r}\text { Sand } \\
\text { Silt } \\
\text { Clay }\end{array}\end{array}$ & $\%$ & $\begin{array}{l}V V_{.} Y \\
13.5 \\
9.3\end{array}$ \\
\hline Textural grade & & Sandy \\
\hline Organic matter & $\%$ & 0.62 \\
\hline $\mathrm{pH}$ (1:2.5 soil/ water suspension) & & 7.8 \\
\hline E.C ( $1: 5$ soil:water extract "TSS") & $\mathrm{dSm}^{-1}$ & 1.2 \\
\hline Total $\mathrm{CaCO}_{3}$ & $\%$ & 3.6 \\
\hline Total $\mathbf{N}$ & $\%$ & 0.15 \\
\hline Total $\mathbf{P}$ & $\%$ & 0.14 \\
\hline Total $\mathrm{K}$ & $\%$ & 0.7 \\
\hline Available $\mathbf{N}$ & $\mathrm{mg} / \mathbf{k g}$ & 12.6 \\
\hline Available P & $\mathbf{m g} / \mathbf{k g}$ & 1.09 \\
\hline Available K & $\mathrm{mg} / \mathbf{k g}$ & 55.22 \\
\hline
\end{tabular}


E. A. Abou-Husssien, et al.,

Table 2: Physical and chemical characterization of molasses (Mols).

\begin{tabular}{|l|c|}
\hline \multicolumn{1}{|c|}{ Properties and units } & Values \\
\hline $\mathrm{pH}$ & 8.2 \\
\hline Specific weight $\mathrm{gm} \mathrm{I}^{-1}$ & 1.39 \\
\hline Total C \% & 44.0 \\
\hline OM \% & 76 \\
\hline Total N \% & 1.13 \\
\hline C/N ratio & $1: 39$ \\
\hline Sugars (\%) & 65 \\
\hline Protein (\%) & 7.1 \\
\hline Solids (\%) & 74 \\
\hline Ash (\%) & 13.3 \\
\hline Total Ca (\%) & 1.0 \\
\hline Total $\mathrm{Mg}(\%)$ & 0.4 \\
\hline Total $\mathrm{Na}(\%)$ & 0.15 \\
\hline Total $\mathrm{K}(\%)$ & 4.3 \\
\hline Total P (\%) & 0.15 \\
\hline
\end{tabular}

Table (3): Physical and chemical characterization of concentrated vinasse (Vins).

\begin{tabular}{|l|r|c|}
\hline \multicolumn{1}{|c|}{ Properties } & Units & \multicolumn{1}{c|}{ Values } \\
\hline $\mathrm{pH}$ & & 4.00 \\
\hline Specific weight & $\mathrm{gm} \mathrm{I}$ & 1.10 \\
\hline Total dissolved solids (TDS) & $(\mathrm{mg} / \mathrm{L})$ & 20146 \\
\hline Dry matter & & 25.32 \\
\hline Total OC \% & & 30.9 \\
\hline C:N Ratio & & $1: 13$ \\
\hline OM \% & & 53.15 \\
\hline Ash & \multirow{2}{*}{$\%$} & 24.32 \\
\hline Reducing sugars & & 4.22 \\
\hline Total N & & 2.37 \\
\hline Total Ca & & 3.14 \\
\hline Total Mg & & 1.21 \\
\hline Total P & & 0.36 \\
\hline Total K & & 6.78 \\
\hline Total Mn & & 4.9 \\
\hline Total Fe & & 44.9 \\
\hline Total Zn & & 1.2 \\
\hline
\end{tabular}


Effect of vinasses, molasses and mineral fertilization on nodulation and .....

\begin{tabular}{|l|r|}
\hline Total $\mathrm{Cu}$ & 5.80 \\
\hline
\end{tabular}

\section{Field experiment}

This study was conducted as a field experiment at Elmarraka village -Tahrire regions, Beheira Governorate, Egypt, during growing summer season of 2016. The studied treatments were arranged within the experimental units in a split randomized block design, with three replicates. The area of each experimental units was $6 \mathrm{~m}^{2}(3 \times 2 \mathrm{~m})$ as shown in Fig (1). Two common beans (Phaseolus vulgaris L) cultivars, i.e. karnack and nebraska commonly cultivated in Egypt were used in this study. Before planting, the seeds of common bean plants were surface-sterilized in $10 \% \mathrm{NaOCl}$ for 10 min, rinsed in distilled water. Then, bean seeds were inoculated with the symbiotic $\mathrm{N}$-fixing bacteria of Rhizobium phaseoli by coating the seeds at a rate of $800 \mathrm{gm}$ of Oqadin /fed., therefore, inoculum level was approximately $1 .{ }^{v}$ CFU (which was confirmed by colony counts on Yeast Mannitol Agar media (YMA), using staking substance (Arabic gum 5\%) just before sowing, which carried out at distance of $25 \mathrm{~cm}$ between each two hills with row spacing of $60 \mathrm{~cm}$. The seeds were sown under drip irrigation system, where irrigation was then carried out at needed. The sowing date was $14^{\text {th }}$ March 2016. Also before sowing the first applications of molasses or concentrated vinasse, were carried out at a rate of 250 $\mathrm{kg} / \mathrm{fed}$.. Phosphoric acid (at a rat: 5 liter $^{\mathrm{fed}^{-1}}$ as commercial phosphoric acid (85\%). At the same time, micronutrients (Fe-Zn-Mn-Cu-B-Mo) were added as abovementioned. All treatments were added under drip irrigation system (Fertigation).

During the growing period: the second addition of molasses, concentrated vinasse, phosphoric acid and micronutrients (Fe-Zn-Mn-Cu-B-Mo) was carried out at pre mentioned application rates of the first one at 15 day after sowing. The third, fourth and fifth additions were added at 25,35 and 50 days after sowing, respectively. The timing of these five additions was in similar with the two common bean cultivars, (Karnack and Nebraska).

The normal cultural practices, i.e. irrigation, fertilization and pest control were followed according to recommendation of Egyptian Ministry of Agriculture. The common fertilizer applications were used as following: $10 \mathrm{~m}^{3} \mathrm{fed}^{-1}$ of farmyard manure were added before planting, mineral $\mathrm{N}$ was added at a rates of $60 \mathrm{Kg} \mathrm{N}^{-1}$ as ammonium nitrate $(33.5 \% \mathrm{~N})$ and $48 \mathrm{~kg} \mathrm{~K}_{2} \mathrm{O}$ fed $^{-1}$ were added as potassium sulfate $\left(48 \%-50 \% \mathrm{~K}_{2} \mathrm{O}\right)$. Added $\mathrm{N}$ and $K$ fertilizers were carried out in three equal doses after 15,35 , and 50 days of planting.

After 45 and 70 days of planting, three plants were taken randomly from each replicates representing the first and second sample, respectively to assess dry natter yield $\left(\mathrm{g} \mathrm{plant}^{-1}\right)$ for the two samples. The nodules number formed on the roots were recorded for each plants harvested at $\mathbf{4 5}$ days. Also, at $\mathbf{4 5}$ days, soil samples were taken from root zone of each replicates to determine dehydrogenase activity "DHA" $\mu$ formazan $\mathrm{g}^{-1}$ hour $^{-1}$, according to Page et al. (1982).

Analysis of variance (ANOVA) and L.S.D test were applied to analyze the obtained results statistically, according to Steel and Torrie (1980).

\section{RESULTS AND DISCUSSION}

\section{Effect of The Studied Treatments on Nodules Number}


Fig (1): The experimental desigg (for one replicate),

\begin{tabular}{|c|c|c|c|c|}
\hline \multicolumn{5}{|c|}{ Molasses } \\
\hline Molasses 0 & Molasses 1 & Molasses 2 & Molasses 3 & Molasses 4 \\
\hline \multicolumn{5}{|c|}{ Karnake (Cultivar l) } \\
\hline \multicolumn{5}{|c|}{ 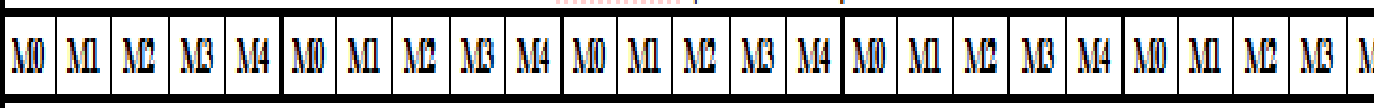 } \\
\hline \multicolumn{5}{|c|}{ Nebraska (Cultivar 2) } \\
\hline \multicolumn{5}{|c|}{ 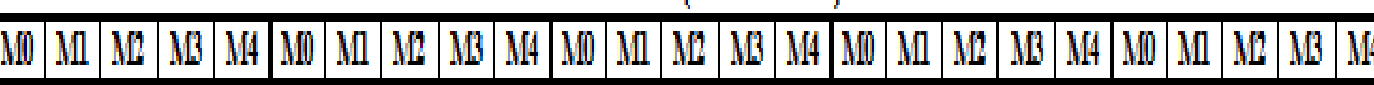 } \\
\hline \multicolumn{5}{|c|}{ Concentrated Vinasse } \\
\hline Vimasse 0 & Vinasse l & Vinasse? & Vinasse 3 & Vinasse 4 \\
\hline \multicolumn{5}{|c|}{ Karnake (Cultivar l) } \\
\hline \multicolumn{5}{|c|}{ 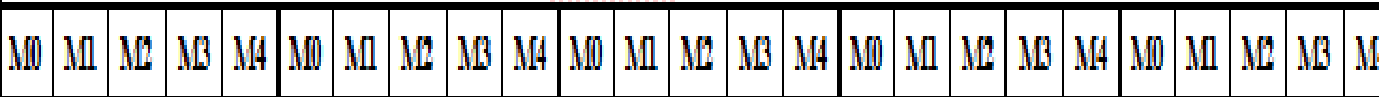 } \\
\hline \multicolumn{5}{|c|}{ Nebraska (Cultirar 2) } \\
\hline 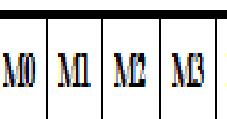 & I & & & \\
\hline
\end{tabular}

where:

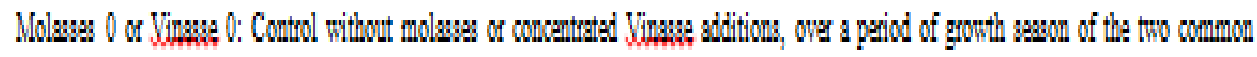

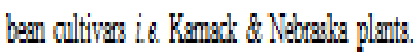

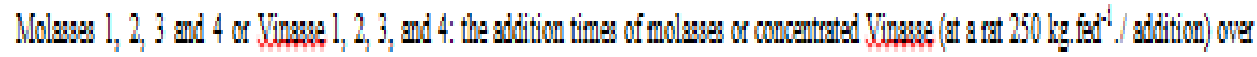
apaind of gowth sason of the two conmon ben altives.

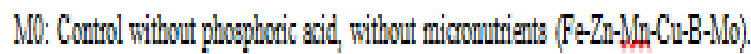

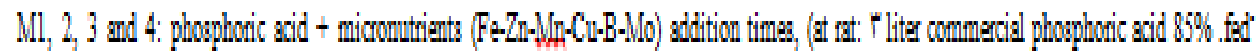

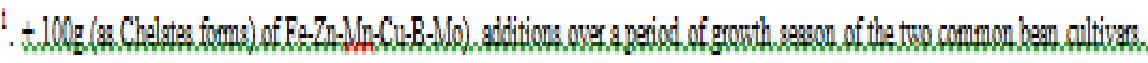

The obtained data of nodules number formed on the roots of two cultivars i.e. Karnack and Nebraska of common bean plants grown on sandy soil under drip irrigation system in relation with the studied organic and mineral fertilizers applications at $\mathbf{4 5}$ days after planting were listed in Table (4). These data reveal at 45 
Effect of vinasses, molasses and mineral fertilization on nodulation and .....

Table (4): Effect of addition times of molasses or vinasses and mineral fertilizers of $P+$ micronutrients on nodule number on the roots of common bean cultivars (Karnack and Nebraska) and its relative change (RC, \%), at 45 day after planting.

\begin{tabular}{|c|c|c|c|c|c|c|c|c|c|}
\hline \multicolumn{2}{|c|}{ Treatments } & \multicolumn{4}{|c|}{ Molasses } & \multicolumn{4}{|c|}{ Vinasses } \\
\hline \multirow{2}{*}{ 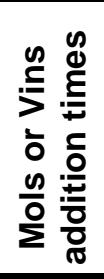 } & \multirow{2}{*}{ 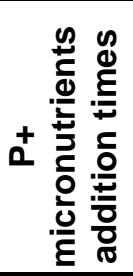 } & \multicolumn{2}{|c|}{ Karnack } & \multicolumn{2}{|c|}{ Nebraska } & \multicolumn{2}{|c|}{ Karnack } & \multicolumn{2}{|c|}{ Nebraska } \\
\hline & &  & 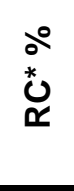 & 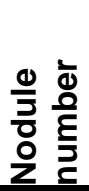 & 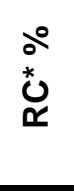 & 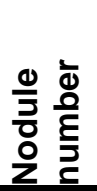 & 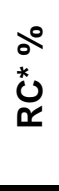 & 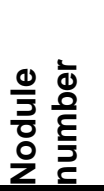 & 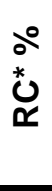 \\
\hline \multirow{4}{*}{ 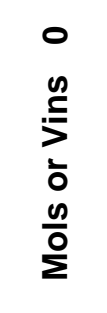 } & MO & 60 & & 66 & & 60 & & 66 & \\
\hline & M1 & 62 & 3 & 68 & 3 & 62 & 3 & 68 & 3 \\
\hline & M2 & 63 & 5 & 68 & 3 & 63 & 5 & 68 & 3 \\
\hline & M3 & 64 & 7 & 69 & 5 & 64 & 7 & 69 & 5 \\
\hline \multicolumn{2}{|c|}{ Mean } & 62 & & 68 & & 62 & & 68 & \\
\hline \multirow{4}{*}{$\begin{array}{l}- \\
0 \\
\stackrel{n}{5} \\
\overline{0} \\
\frac{0}{0} \\
0\end{array}$} & MO & 63 & 5 & 68 & 3 & 71 & 18 & 69 & 5 \\
\hline & M1 & 76 & 27 & 71 & 8 & 72 & 20 & 72 & 9 \\
\hline & M2 & 79 & 32 & 73 & 11 & 74 & 23 & 78 & 18 \\
\hline & M3 & 83 & 39 & 76 & 15 & 76 & 27 & 86 & 30 \\
\hline \multicolumn{2}{|c|}{ Mean } & 76 & & 72 & & 73 & & 76 & \\
\hline \multirow{4}{*}{$\begin{array}{l}N \\
0 \\
\vdots \\
\vdots \\
\vdots \\
0 \\
\frac{0}{0} \\
\sum\end{array}$} & MO & 68 & 13 & 75 & 14 & 75 & 25 & 76 & 15 \\
\hline & M1 & 79 & 32 & 92 & 39 & 84 & 40 & 90 & 36 \\
\hline & M2 & 82 & 37 & 93 & 41 & 86 & 43 & 94 & 42 \\
\hline & M3 & 88 & 47 & 96 & 14 & 88 & 47 & 99 & 50 \\
\hline \multicolumn{2}{|c|}{ Mean } & 76 & & 76 & & 74 & & & \\
\hline \multirow{4}{*}{$\begin{array}{l}m \\
0 \\
0 \\
\vdots \\
\vdots \\
0 \\
\frac{0}{0} \\
\sum\end{array}$} & MO & 68 & 13 & 75 & 14 & 75 & 25 & 76 & 15 \\
\hline & M1 & 79 & 32 & 92 & 39 & 84 & 40 & 90 & 36 \\
\hline & M2 & 82 & 37 & 93 & 41 & 86 & 43 & 94 & 42 \\
\hline & M3 & 88 & 47 & 96 & 45 & 88 & 47 & 99 & 50 \\
\hline \multicolumn{2}{|c|}{ Mean } & 79 & & 91 & & 84 & & 89 & \\
\hline \multicolumn{10}{|c|}{ L.S.D. at 0.05 for treatments of: } \\
\hline \multirow{2}{*}{\multicolumn{5}{|c|}{$\begin{array}{l}\text { Mols or Vins addi } \\
P+\text { Micronutrients }\end{array}$}} & \multicolumn{2}{|c|}{0.589} & & \multicolumn{2}{|c|}{0.611} \\
\hline & & & & & \multirow{2}{*}{\multicolumn{2}{|c|}{$\begin{array}{c}0.589 \\
0.416\end{array}$}} & & \multicolumn{2}{|c|}{0.611} \\
\hline \multicolumn{4}{|c|}{ Cultivars } & & & & & 0.43 & \\
\hline
\end{tabular}


P+ Microelements: P: Phosphoric acid+ Microelements (Fe-Zn-Mn-Cu -B-Mo). (RC, \%): the difference between the value of a particular treatment and control, calculated as percent of that control.

days that, nodules number was increased significantly as a result of organic and mineral fertilizers applications. The rate of these increases, as shown from the relative changes "RC" values (\%) of nodules number affected by the studied treatments were positive and varied widely from treatment to another as well as from cultivar to another. At the same treatment of individual and combined applications of added organic fertilizers (Molasses or concentrated Vinassese) and mineral fertilizers $(P+$ micronutrients), nodules number formed on the roots of Nebraska cultivar was higher than that formed on the roots of Karnack cultivar. These findings refer to, Nebraska cultivar have a high response to added fertilizers compared to Karnack cultivars. Also, these findings show the importance of both organic and mineral fertilization in enhancing nodulation on the roots of common bean grown on sandy soil conditions Regarding to the effect of molasseses and vinasses on the nodules number formed on the roots of Karnack and Nebraska cultivars of common bean plants as listed in Table (4) noted that, there are a significant increases in the number of nodules as a result of organic fertilizers applications compared to the control as well as the plants received mineral fertilization alone. These increases resulted from improving the effect of added organic fertilizers on soil properties in wherever it decrease soil $\mathrm{pH}$ and increase nutrients availability as pointed by Abou Hessien et al. (2017). Abd El-Aal (2018) who found a decrease in soil $\mathrm{pH}$ and increase in the soil content of available essential plant nutrients in the desert soil of Egypt manured by filter cake and other products of sugar cane industries.

Also, molasses and vinasses considered a rich energy source for soil microorganisms resulted from their content of sugars. At the same application time of both molasseses and vinasses with mineral fertilizers, nodules number on the roots of common bean plants fertilized by vinasses was higher than that molasseses application with Karnack and Nebraska cultivars. This effect related with chemical composition of both molasses and vinasses. Based on the mean nodules number for the three applications of vinasses and molasses, it could be noted that, the highest number was found with the applications at 25 days (Mols 3 or Vins 3 ) followed by those recorded with application at 35 days (Mols 2 or Vins 2) with the two cultivars of common been plants (Karnack and Nebraska). Where these means were 79 and 84 for Karnack cultivars and were 91 and 89 for Nebraska cultivars at applications of 35 days, respectively. These findings to ascribed to that organic fertilizers showed more efficiency on nodulation at growth period of 35 days than the other growth periods with the two cultivars grown on sandy soil conditions. Otieno et al. (2009) pointed out a similar enhancing effect of organic fertilizers on nodulation on the leguminous plants roots.

In addition, mineral fertilization as $\mathbf{P}$ and micronutrients resulted in $a$ significant by promote the nodules numbers formed on the roots of Karnack and Nebraska cultivars compared to the control treatment (without organic and mineral fertilization). At the same application of organic fertilizers, the highest number of nodules was found with the plants received M2 of mineral fertilizers with Karnack cultivars and with M3 of mineral fertilizers for Nebraska cultivars. These findings appears a wide variation in the two cultivars response to application times of mineral fertilization. 
Nodule number, weight and volume also increased with the addition of $P$, indicating to its beneficial on N2-fixation (Singh et al., 2008). Nitrogen fixation in common bean has also been established to be more affected by $P$ deficiency than in other legume crops such as soybean (Fageria and Baligar, 2016), while Gidago et al. (2011) reporting adequate $P$ rates for maximum yield and yield attributes as high as $40 \mathrm{~kg} \mathrm{ha}^{-1}$.

El-Shinnawi et al. (201:) pointed out that, under sandy and calcareous soils condition nodules number on the roots of faba bean plants increased significantly as a result of micronutrients applications. The legume crops have more demand for $\mathrm{P}$ for optimal $\mathrm{N}$-fixation compared to nonmodulating plants like cereals because of $P$ having a crucial role in nodule energetic transformations (Rotaru, 2009). Phosphorus supplement in legumes has great potential for promoting growth and higher yield, increases nodule number, as well as enhances symbiotic establishment for increased $\mathrm{N}$-fixation (Ndakidemi et al., 2011). According to Hamer et al. (2009), soil microorganisms may be activated by the supplied easily available organic substrates (vinasses and molasses), thereby, enhancing the mineralization of native soil OM (priming effect), especially in combination with $\mathrm{N}$ fertilization.

\section{Effect of The Studied Treatments on Dehydrogenase Activity}

The presented data in Table (5) manifested the dehydrogenase activity (ug formazan $\mathrm{g}^{-1}$ soil hour ${ }^{-1}$ ) in the root zone of common bean plants grown in sandy soil after 45 days of planting in relation with application time of organic (molase and vinase) and mineral fertilizers $(P+$ micronutrients). These data reveals that there a wide range of DHA in the root zone of common bean plants depending on the cultivated cultivare and both source and application time of both organic and mineral fertilizers. All treatments of fertilization significantly stimulated DHI compared to the control treatment. Combined applications of organic and mineral fertilizer were associated by more increase of DHA compared to those resulted from their individual applications. These results may be cleared from the calculated values of RC (\%) which were positive with all fertilization treatments under study. These findings means that, the added fertilizers have on enhanced effect on the activity of soil microorganisms and improved soil biochemistry, where these fertilizers considered as an important source of energy and essential nutrients.

With the same fertilization treatment, DHA in the root zone of Nebraska cultivars plants was higher than that one of Karnak cultivar. For example with the combined treatment of Mols 3 and M3, DHA in the root zone of Karnack and Nebraska cultivars were 128.10 and 134.00 ug formazan $g^{-1}$ soil hour ${ }^{-1}$, respectively (Table 5).

Also, data in Table (5) postulate that, at the same application time of both organic and mineral fertilizers, DHA in the root zone of common been plants (Karnack and Nebraska) fertilized by vinase was higher than that found with the plants fertilized by molase. For example, DHA in the root zone of Karnack cultivare plants were 128.10 and $134.00 \mu \mathrm{g}$ formazan $\mathrm{g}^{-1}$ soil hour ${ }^{-1}$, with the treatments of Mols 3 combined with M3 and Vins 3 combined with M3 were 143.00 and $154.40 \mu \mathrm{g}$ formazan $\mathrm{g}^{-1}$ soil hour $^{-1}$, respectively. This trend is in harmony with the chemical composition of added organic fertilizer and its suitability for decomposition and also to the effect of decomposition products on soil properties and biochemistry. 
In addition application time of both organic and mineral fertilizers have a important role on DHA in the root zone of common bean plants, where the highest values of DHA was found in the root zone of the plants received the added fertilizers at 35 days of planting (latter additions) compared with the earlier applications (at 0,15 and 25 days of planting). This trend was found in the root zone of both Karnack and Nebraska cultivares. For example, DHA in the root zone of Karnack cultivar fertilized only by mineral fertilizer increased from $86.6 \mu \mathrm{g}$ formazan $\mathrm{g}^{-1}$ soil hour ${ }^{-1}$ with the treatment of MO to $99.20 \mu \mathrm{g}$ formazan $\mathrm{g}^{-1}$ soil hour ${ }^{-1}$ with the treatment of M3 with RC value of $23 \%$.

Table (5): Effect of addition times of molasses or vinasses and mineral fertilizers of $\mathbf{P}+$ some Microelements on dehydrogenase activity and its relative changes (RC, $\%)$, in the rhizosphere soil of bean plants at $\mathbf{4 5}$ days after sowing.

\begin{tabular}{|c|c|c|c|c|c|c|c|c|c|}
\hline \multirow{2}{*}{\multicolumn{2}{|c|}{ Treatments }} & \multicolumn{4}{|c|}{ Molasses } & \multicolumn{4}{|c|}{ Vinasse } \\
\hline & & \multicolumn{8}{|c|}{ Common bean cultivars } \\
\hline \multirow{2}{*}{ 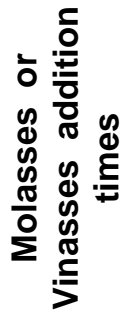 } & \multirow{2}{*}{ 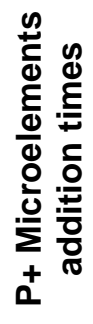 } & \multicolumn{2}{|c|}{ Karnack } & \multicolumn{2}{|c|}{ Nebraska } & \multicolumn{2}{|c|}{ Karnack } & \multicolumn{2}{|c|}{ Nebraska } \\
\hline & & 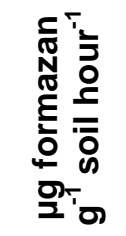 & $\begin{array}{l}0^{\circ} \\
0 \\
0 \\
\end{array}$ & 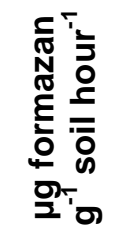 & \begin{tabular}{l}
$\circ$ \\
0 \\
0 \\
\hdashline
\end{tabular} & 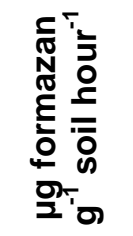 & $\begin{array}{l}\circ \\
0 \\
0 \\
0\end{array}$ & 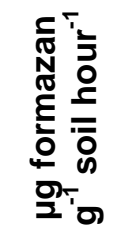 & 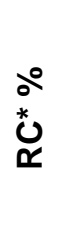 \\
\hline \multirow{4}{*}{$\begin{array}{l}0 \\
\text { O) } \\
\stackrel{5}{5} \\
\dot{\vdots} \\
\text { on } \\
\stackrel{0}{\Sigma}\end{array}$} & MO & 80.60 & - & 81.90 & - & 80.60 & - & 80.70 & - \\
\hline & $M_{1}$ & 89.50 & 11 & 91.30 & 11 & 89.50 & 11 & 89.90 & 11 \\
\hline & $\mathbf{M}_{2}$ & 94.30 & 17 & 97.10 & 19 & 94.30 & 17 & 95.60 & 19 \\
\hline & $\mathbf{M}_{3}$ & 99.20 & 23 & 101.20 & 24 & 99.20 & 23 & 99.80 & 24 \\
\hline \multicolumn{2}{|c|}{ Means } & 92.82 & & & & & & & \\
\hline \multirow{4}{*}{$\begin{array}{l}\overline{5} \\
\stackrel{0}{5} \\
\vdots \\
\overline{0} \\
0 \\
\frac{0}{0} \\
\sum\end{array}$} & $\mathbf{M}_{0}$ & 86.00 & 7 & 87.30 & 7 & 96.00 & 19 & 99.40 & 21 \\
\hline & $M_{1}$ & 103.90 & 29 & 93.70 & 14 & 102.40 & 27 & 106.00 & 29 \\
\hline & $\mathbf{M}_{2}$ & 103.90 & 29 & 108.30 & 32 & 114.90 & 43 & 119.00 & 45 \\
\hline & $\mathbf{M}_{3}$ & 118.80 & 47 & 124.60 & 52 & 120.30 & 49 & 129.20 & 58 \\
\hline \multicolumn{2}{|c|}{ Means } & 106.84 & & & & & & & \\
\hline \multirow{3}{*}{$\begin{array}{l}N \\
0 \\
\stackrel{0}{5} \\
\vdots \\
0 \\
\frac{0}{0} \\
\stackrel{0}{\Sigma}\end{array}$} & $M_{0}$ & 86.00 & 7 & 88.00 & 7 & 102.70 & 27 & 106.40 & 30 \\
\hline & $M_{1}$ & 95.30 & 18 & 96.30 & 18 & 111.00 & 38 & 118.70 & 45 \\
\hline & $\mathbf{M}_{2}$ & 113.20 & 40 & 113.70 & 39 & 129.00 & 60 & 134.40 & 64 \\
\hline
\end{tabular}


Effect of vinasses, molasses and mineral fertilization on nodulation and .....

\begin{tabular}{|c|c|c|c|c|c|c|c|c|}
\hline $\mathbf{M}_{3}$ & 122.30 & 52 & 130.00 & 59 & 140.00 & 74 & 150.20 & 83 \\
\hline Means & 109.16 & & 113.72 & & 127.74 & & 133.66 & \\
\hline
\end{tabular}

Table (5). Cont.

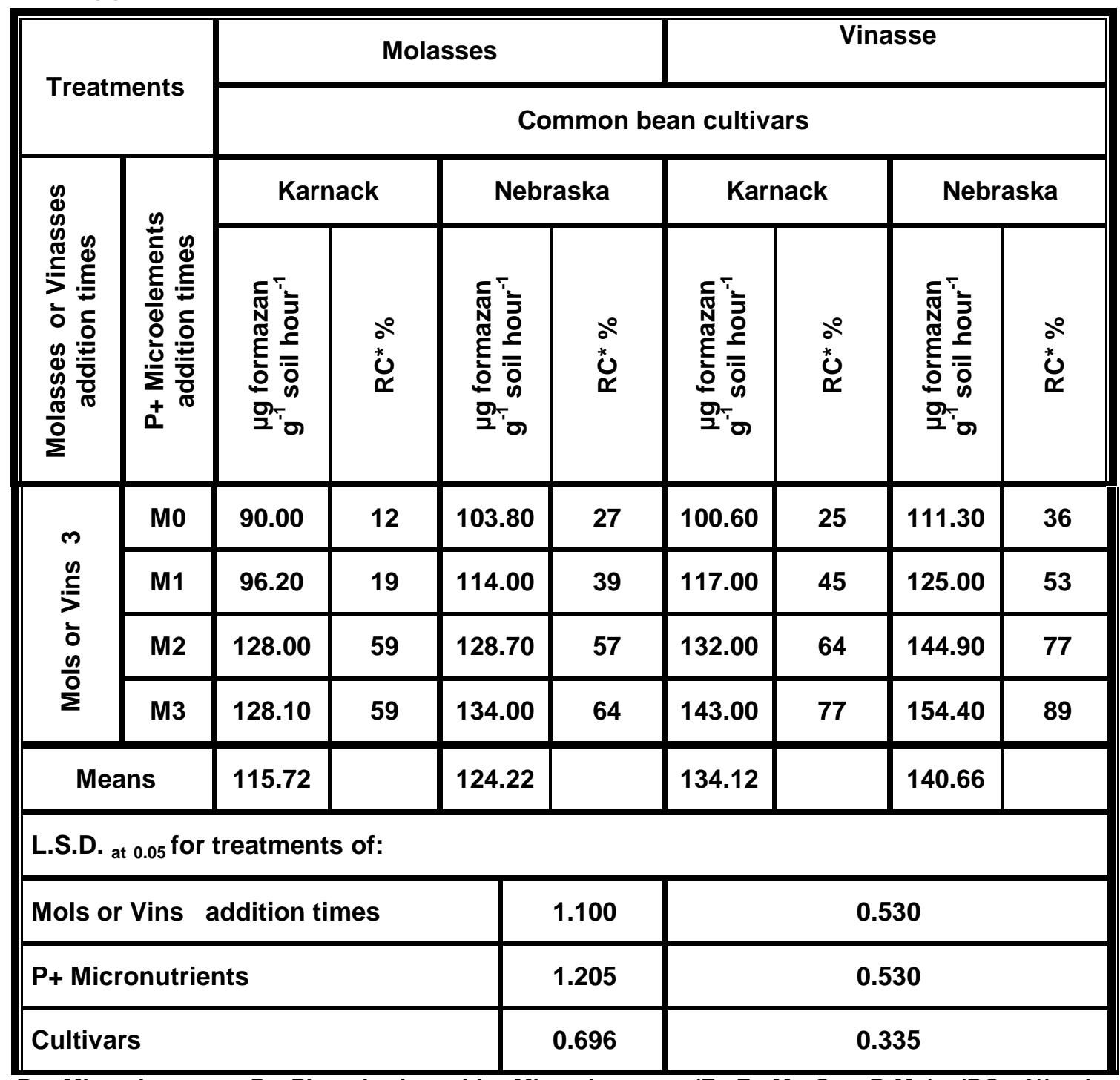

P+ Microelements: P: Phosphoric acid+ Microelements (Fe-Zn-Mn-Cu -B-Mo). (RC, \%): the difference between the value of a particular treatment and control, calculated as percent of that control.

\section{Effect of The Studied Treatments} on Dry Matter Yields (DMY) of Common Bean Plant.

Dry matter yield's "DMY" as $\mathrm{g} \mathrm{plant}^{-1}$ of common bean plants cultivars i.e Karnack and Nebraska grown on sandy soil under drip irrigation system in relation with both fertilizers type i.e. organic (molasses and vinasses) and mineral ( $\mathrm{P}_{+}$micronutrients) and its application time $(0,15,25,35$ and 50 days) of planting were determined at two growth periods i.e 45 and 70 days of planting. The obtained data are recorded in Tables ( 6 and 7 ). These data may be summarized as follows. 
- At two growth periods as well as with the same application of organic and mineral fertilizers, the dry matter yields of Nebraska cultivars were higher than those found with Karnack cultivars. These findings cleared high response of Nebraska cultivars to the tested treatments of fertilization compared to that found with Karnack cultivars.

-Individual applications of mineral fertilizers $\quad(P+\quad$ micronutrients) significantly increasd the DMY of common been plants at two growth periods, where the rate of these raised (RC, \%) varied widely from cultivars to another as well as with application time. For example, DMY of Karnack cultivars were increased from 9.98 and $42.91 \mathrm{~g}$ plant $^{-1}$ in the control treatment (Mo) to 12.97 and $46.44 \mathrm{~g} \mathrm{plant}^{-1}$ with mineral fertilizers applied at 35 days of planting and increased from 12.97 and 35.93 to 15.97 and $44.4 \mathrm{~g} \mathrm{plant}^{-1}$ with the same treatments of mineral fertilizers at 45 and 70 day of planting. The enhanced effect of $P$ and micronutrients on plant growth and its dry matter yields was mentioned by Emam (2018) on barley plants grown on sandy soil. Also, ElShinnawi et al. (2014) found a significant increase in faba bean plants dry matter yields grown on sandy and calcareous soils.

-Individual applications of molasses and vinasses significantly stimulated the common bean plants cultivars dry matter yields $\left(g\right.$ plant $\left.^{-1}\right)$, where the highest dry matter yields of the two cultivars (Karnack and Nebraska) were obtained at the application time of 35 and $\mathbf{5 0}$ days of growth periods at $\mathbf{4 5}$ and 70 days, respectively. Also, at the same application time of organic fertilizers, dry matter yields of Nebraska and Karnack cultivars fertilized by vinasses were higher than those found of the plants fertilized by Molasses at both 45 and 70 days of planting. This results are obviously recorded from RC (\%) of dry matter yields of the two cultivars under different application time of molasses and vinasses, where the found RC (\%) values with the treatments of vinasses were higher than those for the application of molasses. In this respect, the obtained results are in agreement with those of Ati and Ali (2011). Also, Ganie et al. (2014) reported that, the application of boron led to an increase in the concentration of $N, P, K$ and $B$ in the seeds of common bean plants (Phaseolus vulgaris L.). These findings show the importance of organic fertilizer source and its chemical composition, which may be used as soil amendment and fertilizer (Hessien, 2019). Fageria and Baligar (2016) reported that, phosphorus is an essential nutrient for various metabolic processes such as photosynthesis, respiration and signal transduction, among others. Phosphorus application on common bean consistently showed a positive response on yield, shoot dry matter and number of pods of common bean plants. This result was similar to those of Turuko and Mohammed (2012), who reported dry matter accumulation increase with application of phosphorus rates. Similarly, significant and linear increase in total dry matter production of common bean plant was observed due to increased phosphorus (Veeresh, 2003).

Combined applications of both organic (molasses and vinasses) and mineral ( $P+$ micronutrients) fertilizers results in a high increase of common bean plants cultivars (Karnack and Nebraska) dry matter yields (g plant ${ }^{-1}$ ) and its relative change "RC" (\%) compared with their individual applications especially at application 
Effect of vinasses, molasses and mineral fertilization on nodulation and .....

time of 35 and 50 days of planting at growth periods of 45 and 70 days. These findings are similar with those obtained by Emam (2018).

Table (6): Effect of addition times of molasses and mineral fertilization ( $P$ and micronutrients) on shoots Dry matter weight "DMY" (g plant ${ }^{-1}$ ) and its relative change (RC, \%) at two growth periods of common bean plants cultivars (Karnack and Nebraska)

\begin{tabular}{|c|c|c|c|c|c|c|c|c|c|}
\hline \multirow{2}{*}{\multicolumn{2}{|c|}{ reatments }} & \multicolumn{8}{|c|}{ Common bean cultivars } \\
\hline & & \multirow{2}{*}{\multicolumn{4}{|c|}{$\begin{array}{c}\text { Karnack } \\
\text { growth periods }\end{array}$}} & \multirow{2}{*}{\multicolumn{4}{|c|}{$\begin{array}{c}\text { Nebraska } \\
\text { growth periods }\end{array}$}} \\
\hline \multirow{3}{*}{ 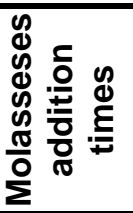 } & \multirow{3}{*}{$\begin{array}{c}\mathrm{P}+ \\
\text { micronutrients } \\
\text { addition times }\end{array}$} & & & & & & & & \\
\hline & & At 45 & days & At 70 & days & At 45 & days & At 70 & days \\
\hline & & g/plant & $\mathbf{R C} \%$ & g/plant & $\mathbf{R C} \%$ & g/plant & $\mathrm{RC} \%$ & g/plant & RC\% \\
\hline \multirow{5}{*}{$\frac{0}{01}$} & $\mathbf{M}_{0}$ & 9.98 & & 42.91 & & 12.97 & & 35.93 & \\
\hline & $\overline{M_{1}}$ & 11.80 & 18.20 & 43.91 & 2.34 & 13.97 & 7.73 & 36.93 & 2.77 \\
\hline & $\overline{M_{2}}$ & 12.64 & 26.70 & 44.91 & 4.66 & 15.97 & 23.11 & 41.92 & $\overline{16.66}$ \\
\hline & $\mathbf{M}_{3}$ & 14.97 & 50.00 & 46.91 & 9.31 & 19.96 & 53.89 & 45.91 & 27.77 \\
\hline & $\mathbf{M}_{4}$ & & & 46.91 & 9.31 & & & 48.90 & 36.10 \\
\hline \multicolumn{2}{|r|}{ Mean } & 12.35 & & 45.11 & & 15.72 & & 41.92 & \\
\hline \multirow{5}{*}{$\frac{\bar{c}}{0}$} & $\overline{M_{0}}$ & 12.81 & 28.36 & 44.61 & 3.96 & 16.78 & 29.35 & 43.17 & 20.15 \\
\hline & $M_{1}$ & 14.57 & 46.00 & 47.01 & 9.55 & 16.97 & 30.81 & 43.69 & 21.60 \\
\hline & $\mathbf{M}_{2}$ & 17.47 & 75.00 & 48.02 & 11.90 & 20.96 & 61.59 & 54.80 & 52.52 \\
\hline & $\mathbf{M}_{3}$ & 18.96 & 90.00 & 51.85 & 20.84 & 24.95 & 92.37 & 61.61 & 71.49 \\
\hline & $\mathrm{M}_{4}$ & & & 59.74 & 39.22 & & & 65.06 & 81.07 \\
\hline \multicolumn{2}{|r|}{ Mean } & 15.95 & & 50.24 & & 19.91 & & 53.67 & \\
\hline \multirow{5}{*}{$\begin{array}{l}N \\
\frac{\infty}{0} \\
\sum\end{array}$} & $\mathrm{M}_{0}$ & 13.97 & 40.00 & 45.56 & 6.17 & 17.96 & 38.50 & 44.90 & 24.96 \\
\hline & $M_{1}$ & 17.96 & 80.00 & 47.63 & 10.99 & 19.96 & 53.89 & 45.44 & 26.46 \\
\hline & $\mathbf{M}_{2}$ & 17.96 & 80.00 & 52.20 & 21.65 & 24.95 & 92.37 & 56.99 & 58.62 \\
\hline & $\mathbf{M}_{3}$ & 18.96 & 90.00 & 55.05 & 28.29 & 26.95 & 107.76 & 64.09 & 78.36 \\
\hline & $\mathbf{M}_{4}$ & & & 52.24 & 21.74 & & & 67.66 & 88.30 \\
\hline \multicolumn{2}{|r|}{ Mean } & 17.22 & & 50.53 & & 22.46 & & 55.82 & \\
\hline \multirow{5}{*}{$\frac{m}{0}$} & $\mathbf{M}_{0}$ & 14.97 & 50.00 & 49.92 & 16.33 & 17.96 & 38.50 & 48.90 & 36.10 \\
\hline & $M_{1}$ & 16.97 & 70.00 & 53.46 & 24.58 & 23.95 & 84.67 & 52.89 & 47.21 \\
\hline & $\mathbf{M}_{2}$ & 18.96 & 90.00 & 53.83 & 25.44 & 26.95 & 107.76 & 64.87 & 80.55 \\
\hline & $M_{3}$ & 18.96 & 90.00 & 55.98 & 30.45 & 25.95 & 100.06 & 68.86 & 91.66 \\
\hline & $\mathbf{M}_{4}$ & & & 60.80 & 41.70 & & & 73.85 & 105.54 \\
\hline \multicolumn{2}{|r|}{ Mean } & 17.47 & & 54.80 & & 23.70 & & 61.87 & \\
\hline \multirow{5}{*}{$\begin{array}{l}\dot{0} \\
\frac{0}{0} \\
\sum\end{array}$} & $\mathbf{M}_{0}$ & & & 52.12 & 21.46 & & & 55.89 & 55.55 \\
\hline & $M_{1}$ & & & 58.87 & 37.20 & & & 56.89 & 58.32 \\
\hline & $\mathbf{M}_{2}$ & & & 62.73 & 46.20 & & & 67.86 & 88.88 \\
\hline & $\mathbf{M}_{3}$ & & & 65.63 & 52.95 & & & 73.85 & 105.54 \\
\hline & $\mathbf{M}_{4}$ & & & 69.42 & 61.79 & & & 80.84 & 124.99 \\
\hline
\end{tabular}


E. A. Abou-Husssien, et al.,

\begin{tabular}{|c|c|c|c|}
\hline Mean & 61.76 & 67.07 & \\
\hline \multicolumn{2}{|c|}{ L.S.D. at 0.05 for treatments of: } & \multicolumn{2}{|c|}{ At 70 days } \\
\hline Mols addition times & 0.139 & \multicolumn{2}{|l|}{0.427} \\
\hline P+ Micronutrients & 0.139 & \multicolumn{2}{|l|}{0.468} \\
\hline Cultivars & 0.099 & \multicolumn{2}{|l|}{0.270} \\
\hline
\end{tabular}

P+ Microelements: P: Phosphoric acid+ Microelements (Fe-Zn-Mn-Cu -B-Mo). (RC, \%): the difference between the value of a particular treatment and control, calculated as percent of that control.

Table (7): Effect of addition times of molasses or vinasses and mineral fertilization (P and micronutrients) on shoots dry weight "DMY" (g plant $\left.{ }^{-1}\right)$ and its relative change (RC, \%) at two growth periods of common bean plants cultivars (Karnack and Nebraska).

\begin{tabular}{|c|c|c|c|c|c|c|c|c|c|}
\hline \multirow{2}{*}{\multicolumn{2}{|c|}{ Treatments }} & \multicolumn{8}{|c|}{ Common bean cultivars } \\
\hline & & \multirow{2}{*}{\multicolumn{4}{|c|}{$\frac{\text { Karnack }}{\text { owth periods }}$}} & \multirow{2}{*}{\multicolumn{4}{|c|}{$\begin{array}{c}\text { Nebraska } \\
\text { growth periods }\end{array}$}} \\
\hline \multirow{3}{*}{ 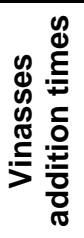 } & \multirow{3}{*}{ 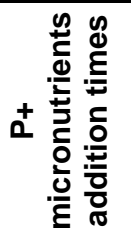 } & & & & & & & & \\
\hline & & At 45 & days & At $7 C$ & lays & At 45 & days & At 70 & days \\
\hline & & g/plant & $\mathbf{R C} \%$ & g/plant & $\mathbf{R C} \%$ & g/plant & $\mathrm{RC} \%$ & g/plant & $\mathrm{RC} \%$ \\
\hline \multirow{5}{*}{$\begin{array}{l}0 \\
\stackrel{0}{0} \\
\stackrel{5}{>}\end{array}$} & $\mathrm{M}_{0}$ & 9.98 & & 42.91 & & 12.97 & & 35.93 & \\
\hline & $M_{1}$ & 11.80 & 18.20 & 43.91 & 2.34 & 13.97 & 7.73 & 36.93 & 2.77 \\
\hline & $M_{2}$ & 12.64 & 26.70 & 44.91 & 4.66 & 15.97 & 23.11 & 41.92 & 16.66 \\
\hline & $M_{3}$ & 14.97 & 50.00 & 46.91 & 9.31 & 19.96 & 53.89 & 45.91 & 27.77 \\
\hline & $\mathrm{M}_{4}$ & & & 46.91 & 9.31 & & & 48.90 & 36.10 \\
\hline \multicolumn{2}{|c|}{ Mean } & 12.35 & & 45.11 & & 15.72 & & 41.92 & \\
\hline \multirow{5}{*}{$\stackrel{\bar{n}}{\stackrel{5}{5}}$} & $M_{0}$ & 12.97 & 30.00 & 46.91 & 9.31 & 16.97 & 30.81 & 44.91 & 24.99 \\
\hline & $M_{1}$ & 14.97 & 50.00 & 49.90 & 16.29 & 21.96 & 69.28 & 44.91 & 24.99 \\
\hline & $\mathrm{M}_{2}$ & 17.96 & 80.00 & 50.90 & 18.62 & 24.95 & 92.37 & 56.89 & 58.32 \\
\hline & $M_{3}$ & 18.85 & 88.90 & 54.89 & 27.92 & 23.95 & 84.67 & 63.87 & 77.77 \\
\hline & $M_{4}$ & & & 62.87 & 46.53 & & & 66.87 & 86.10 \\
\hline \multicolumn{2}{|c|}{ Mean } & 16.19 & & 53.09 & & 21.96 & & 55.49 & \\
\hline \multirow{5}{*}{$\begin{array}{l}N \\
\stackrel{N}{E} \\
\stackrel{5}{>}\end{array}$} & $M_{0}$ & 15.29 & 53.20 & 47.90 & 11.64 & 17.96 & 38.50 & 46.91 & 30.55 \\
\hline & $M_{1}$ & 20.25 & 102.90 & 49.90 & 16.29 & 23.95 & 84.67 & 46.91 & 30.55 \\
\hline & $M_{2}$ & 20.61 & 106.50 & 54.89 & 27.92 & 26.95 & 107.76 & 58.88 & 63.88 \\
\hline & $M_{3}$ & 21.86 & \begin{tabular}{|l|}
119.00 \\
\end{tabular} & 57.88 & 34.90 & 27.94 & 115.45 & 65.87 & 83.32 \\
\hline & $M_{4}$ & & & 63.87 & 48.85 & & & 69.86 & 94.43 \\
\hline \multicolumn{2}{|c|}{ Mean } & 19.50 & & 54.89 & & 24.20 & & 57.68 & \\
\hline \multirow{5}{*}{$\begin{array}{l}\infty \\
\stackrel{n}{5}\end{array}$} & $\mathbf{M}_{0}$ & 16.83 & 68.60 & 53.89 & 25.59 & 18.68 & 44.04 & 51.36 & 42.93 \\
\hline & $M_{1}$ & 21.46 & 115.00 & 54.89 & 27.92 & 24.91 & 92.06 & 57.08 & 58.86 \\
\hline & $M_{2}$ & 23.62 & \begin{tabular}{|l|}
136.70 \\
\end{tabular} & 55.89 & 30.24 & 28.02 & 116.07 & 68.14 & 89.64 \\
\hline & $M_{3}$ & 26.95 & \begin{tabular}{|l|}
170.00 \\
\end{tabular} & 57.88 & 34.90 & 29.94 & 130.84 & 72.03 & 100.47 \\
\hline & $M_{4}$ & & & 62.87 & 46.53 & & & 75.47 & 110.05 \\
\hline \multicolumn{2}{|c|}{ Mean } & 22.21 & & 57.09 & & 25.39 & & 64.81 & \\
\hline \multirow{5}{*}{$\begin{array}{l}\dot{\nabla} \\
\stackrel{\infty}{\Xi} \\
\stackrel{5}{>}\end{array}$} & $M_{0}$ & & & 55.89 & 30.24 & & & 56.76 & 57.97 \\
\hline & $M_{1}$ & & & 62.87 & 46.53 & & & 64.00 & 78.12 \\
\hline & $M_{2}$ & & & 66.87 & 55.83 & & & 68.95 & 91.90 \\
\hline & $M_{3}$ & & & 68.86 & 60.48 & & & 75.10 & 109.01 \\
\hline & $M_{4}$ & & & 72.85 & 69.78 & & & 82.18 & 128.72 \\
\hline
\end{tabular}


Effect of vinasses, molasses and mineral fertilization on nodulation and .....

\begin{tabular}{|c|c|c|}
\hline Mean & 65.47 & 69.40 \\
\hline \multicolumn{2}{|c|}{ L.S.D. at 0.05 for treatments of: } & At 70 days \\
\hline Vinas addition times & $.10 \leqslant$ & $\cdot . \wedge \varepsilon$ \\
\hline P+ Micronutrients & $.10 \leq$ & $\cdot r \wedge \varepsilon$ \\
\hline Cultivars &. .1 .9 & $\cdot r \leqslant r$ \\
\hline
\end{tabular}

P+ Microelements: P: Phosphoric acid+ Microelements (Fe-Zn-Mn-Cu -B-Mo). (RC, \%): the difference between the value of a particular treatment and control, calculated as percent of that control.

\section{REFERENCES}

Abd El-Aal, M. A. M. (2018). Studies on improving of some desertic soils properties and their implications on plants. M. Sc. Thesis Fac. of Agric., Benha Univ., Egypt.

Abou Hessien, E. A., W. M. Nada and M. Kh. Elgezery (2017). Evaluation efficiency of sulphur fertilizer in calcareous soil amended by compost. Menoufia J. Soil Sci., 2 (February): 5972.

Ati, A. S. and N. S. Ali (2011). The effect ofboron fertilization on Faba bean (Viciafaba L) yield, fertilizer and water productivity. Researches of the First International Conference (Babylon and Universities): 2072-3875.

Broadley, M., P. Brown, I. Cakmak, Z. Rengel and F. Zha (2012). Functions of nutrient: micronutrients. In: Marschner P (ed) Marschner's mineral nutrition of higher plants, 3rd edn. Elsevier, Oxford, pp 243-248.

Cottenie, A., M. Verloo, L. Kiekens, G. Velghe and R. Amertynck (1982). Chemical Analysis of Plants and Soils. Laboratory of Analytical and Agrochemistry State University, Ghent, Belgium., pp.50-70.Curtin, L.V., (1983). Molasses- General Considerations. National Feed Ingredients Association West Des Moines, lowa http://rcrecona.ifas.ufl.edu/pdf/publications/mola sses-general-considerations..pdf.

Elkhatib, H.A. (2009). Growth and yield of common bean (Phaseolus vulgaris L.) in response to rhizobium inoculation, nitrogen and molybdenum fertilization. ALEXANDRIA Alexandria Science Exchange J., 30 (2):319-332.

El-Shinnawi, MM., T. M. Waly, H.M. ElZemrany and N. El-Noamany (2014). Impact of micronutrients and dinitrogen fixers on faba bean plant growth in alluvial and calcareous soils. Minufiya J. Agric. Res. 39 (2): 371-385.

Emam, A.A.E. (2018). Effect of some organic fertilizers on plant irrigated by saline water. Ph. D. Thesis, Fac. of Agric., Menoufia Univ., Egypt.

Fageria, N.K. (2002). Nutrient management for sustainable dry bean production in the tropics. Communications in Soil Science and Plant Analysis, 33(9):1537-1575. DOI:10.1081/CSS-120004299

Fageria, N.K. and V.C. Baligar (2016). Growth, yield and yield components of dry bean as influenced by phosphorus in tropical acid soil. J. Plant Nutr., 3: 562-568.

FAO, (2013). FAOSTAT. Available from http://faostat.fao.org/faostat/ collections Subset agriculture.

FAO, (2016). Statistical Data Warehouse. http://data.fao.org/es/statistics. Accessed December 2016.

Ganie, M. A., F. Akhter, G. R. Najar and M. A. Bhat (2014). Influence of sulphur and boron supply on nutrient content and uptake of French bean (Phaseolus vulgaris L.) under inceptisols of North Kashmir. African Journal of Agricultural Research, 9 (2): 230-239.

Gidago, G., S. Beyene, W. Worku and E. Sodo (2011). The response of haricot 
bean (Phaseolus vulgaris L.) to phosphorus application on Ultisols at Areka, Southern Ethiopia. J. Biol. Agric. Healthcare, 1: 38-49.

Hamer, U., K. Potthast and F. Makeschin (2009). Urea fertilization affected soil organic matter dynamics and microbial community structure in pasture soils of Southern Ecuador. Applied Soil Ecology, 43: 226-233.

Hessen, A. M. A. (2019). Effect of gamma rays on properties of Leucaena Leucocephala compost under field conditions. M. Sc. Thesis Fac. of Agric., Menoufia Univ., Egypt.

Jiang, Z.P., Y.R. Li, G.P. Wei, Q. Liao, T.M. Su, Y.C. Meng, H.Y. Zhang and C.Y. Lu (2012). Effect of Long-Term Vinasse Application on Physicochemical Properties of Sugarcane Field Soils. Sugar Technol. 14(4):412417. http://dx.doi.org/10.1007/s12355012-0174-9

Klute, A. (1986). Methods of Soil Analysis, Part 2: Physical and Mineralilogical Properties. Amer. Soc. Agron. Inc. Madison, Wise., USA.

Ndakidemi, P.A., S. Bambara and JHJR. Makoi (2011). Micronutrient uptake in common bean (Phaseolus vulgaris $\mathrm{L}$ ) as affected by Rhizobium inoculation, and the supply of molybdenum and lime. Plant Omics, J. 4(1): 40-52.

Oldroyd, G.E. and R. Dixon (2014). Biotechnological solutions to the nitrogen problem. Curr. Opin. Biotechnol, 26: 19-24.

Otieno, P.E., J.W. Muthomi, G.N. Chemining'wa and J.H. Nderitu (2009). Effect of rhizobia inoculation, farm yard manure and nitrogen fertilizer on nodulation and yield of food grain legumes. J. biological Sciences, 9(4):326-332.

Page, A.L., R. H. Miller and D.R. Keeny (Ed.) (1982). Methods of Soil Analysis, Part 2 Chemical and Biological Properties. American Society of
Agronomy Inc. Mascson, Wisconsin USA.

Prado, R.D.M., G. Caione and C.N.S. Campos (2013). Filter cake and vinasse as fertilizers contributing to conservation agriculture. Applied and Environmental Soil Science. https://doi.org/10.1155/2013/581984 article ID 581984, 8p.

Rotaru, V. and T.R. Sinclair (2009). Interactive influence of phosphorus and iron on nitrogen fixation by soybean. Environ Exp Bot 66 (1):9499.

Turuko, M. and A. Mohammed (2014). Effect of different phosphorus fertilizer rates on growth, dry matter yield and yield components of common bean (Phaseolus vulgaris L.). World J. Agricultural Research, 2(3): 88-92. DOI:10.12691/wjar-2-3-1

Singh, R.P., S.C. Gupta and A.S. Yadav (2008). Effect of levels and sources of phosphorus and PSB on growth and yield of blackgram. Legume. Res., 31: 139-141.

Steel, R. G. B. and J.H. Torrie (1980). Principles and Procedures of statutes. 2nd ED. C. Graw-Hill. Inc. P. 633.

Udvardi, M. and P.S. Poole (2013). Transport and metabolism in legumerhizobia symbioses. Annu. Rev. Plant Biol., 64: 781-805.

Vance, C.P., C. Uhde-Stone and DL. Allan (2003). Phosphorus acquisition and use: critical adaptations by plants for securing a nonrenewable resource. New Phytol., 157: 423-447

Veeresh, N.K. (2003). Response of French bean (Phaseolus vulgaris L.) to fertilizer levels in Northern Transitional Zone of Karnataka" M.Sc. (Agri.) Thesis, Univ. Agric. Sci., Dharwad. 37-79.

Voortman, R. and P.S. Bindraban (2015). Beyond $N$ and $P$ : toward $a$ land resource ecology perspective and impactful fertilizer interventions in 
Sub-Saharan Africa. VFRC Report 2015/1. Virtual Fertilizer Research Center, Washington, DC, USA, pp 49 Yadav, G.S., S. Babu, R.S. Meena, C. Debnath, P. Saha, C. Debbaram and M. Datta (2017). Effects of godawariphosgold and single supper phosphate on groundnut (Arachis hypogaea) productivity, phosphorus uptake and phosphorus use efficiency and economics. Indian J. Agri. Sci., 87 (9): 1165-1169.

Zhang, Z., H. Liao and WJ. Lucas (2014). Molecular mechanisms underlying phosphate sensing, signaling, and adaptation in plants. J. Integr. Plant Biol., 56:192-220.

تأثير إضافة الفيناس، المولاس والتسميد المعدني على عملية التعقيد ونمو نباتات الفاصوليا تحت ظروف الأراضي الرملية المستصلحة

الحسيني أبو حسين، حمدي الزمراني، محمد بخيت حماد

قسم علـوم الأراضسي ـ كلية الزراعة ـ جامعة المنوفية ـ مصر.

الملخص العربي

تم تنفيذ التجربة الحالية لتحقيق الأهداف التالية: تقييم تأثير إضافة كلا من المولاس أو الفيناس المركز مع الأسمدة المعدنية مثل حض الفوسفوريك ومزيج من بعض العناصر الصغري Fe-Zn-Mn-Cu-B-Mo)، حيث تم إضافتها أريع جرعات متساوية عند مراحل نمو مختلفة، إلى صنفين من نباتات الفاصوليا (Phaseolus vulgaris L.)

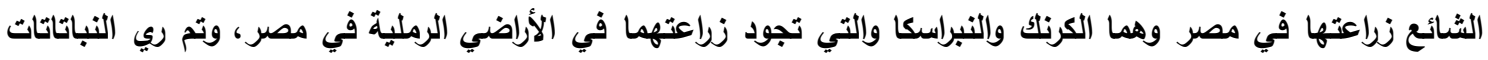
بنظام الري بالتقيط، علي عملية التعقيد، ونشاط إنزيم الايهيدرجينيز عند ه ؛ يومًا من الزراعة ، وكذللك محصول المادة الجافة لنبات الفاصوليا علي فترتي نمو ه ؛ و V يومًا بعد الزراعة. أظهرت نتائج الدراسة وجود إختلافات واسعة لإستجابة نباتات صنفي الفاصوليا (الكرنك ونبراسكا) على نطاق واسع من معاملات التجرية إلى أخرى، فقد أدي التسميد العضوي بالفيناس او بالمولاس مناست منفردا أو مصحويا بالتسميد المعدني

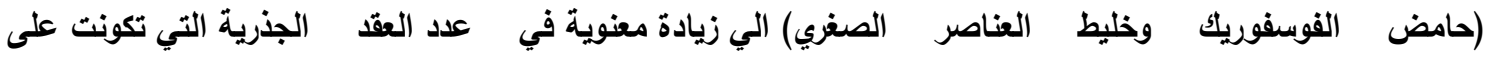

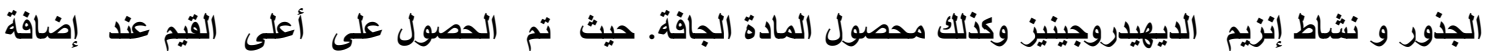
الفيناس مع صنف النبراسكا مقارنة مع صنف الكرنك في جميع القياسات. 


$$
\begin{aligned}
& \text { السادة المحكمين } \\
& \text { أ.د/ منال فتحى طنطـــــــاوى مركز البحوث الزراعية - الجيزة }
\end{aligned}
$$

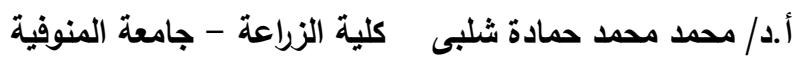

